\title{
INTERNAL FACTORS WHICH DETERMINE FINANCIAL PERFORMANCE OF FIRMS: WITH SPECIAL REFERENCE TO OWNERSHIP CONCENTRATION
}

\author{
Chandrapala Pathirawasam ${ }^{1}$ \\ ${ }^{1}$ University of Kelaniya, Faculty of Commerce and Management Studies, Dalugama, Kelaniya, Sri Lanka \\ Email:Pathi3@yahoo.com
}

\begin{abstract}
The purpose of this paper is to examine the impact of ownership concentration and other firm specific factors on company financial performance of 102 listed companies at Colombo Stock Exchange (CSE) over a two-year period from 2008 to 2009. The data are gathered through annual reports of respective companies. Both pooled and ordinary least square (OLS) regressions are used to analyze the data. Using ROA as the dependent variable, it is revealed that ownership concentration does not have a significant positive relationship with ROA. However, firm size, quick ratio and inventory having positive impact on ROA. But the debt ratio negatively relate with financial performance. The overall explanatory power of the model is below average and further research is necessary to increase the statistical power of the model.
\end{abstract}

Keywords: Colombo Stock Exchange, financial performance, ownership concentration, returns on assets.

JEL classification: M41, L25

Doručeno redakci: 8.11.2010; Recenzováno: 21.1.2013; 14.1.2013; 9.2.2013; Schváleno k publikování: 16.4.2013

\section{Introduction}

Economists believe that the main objective of a firm is to maximize profits. Hence profitability of a firm has become the major criterion in determining its financial performance. Particularly investors concern the profitability of the company. Hence, they try to involve with affairs of the firm in various means. However, in modern turbulent business environment, investors (owners) have to recruit managers as their agents to play essential roles on behalf of them. But, agency theory shows that sometimes managers work for their interest (high compensation, low efforts, expense preference, luxury facilities etc. known as diversification strategy in strategic management) rather than maximizing wealth for shareholders.

Agency theoretic research has studied the impacts of conflicts between behaviors of owners and managers on performance of companies. They focus specially on diversification motive of managers and controls of owners to avoid them. One of the indications of best corporate governance control over managers' decisions is how far ownership of the firm is concentrated on major shareholders and its impact on finance performance. This has been studied recently by many researchers (e.g., Tomsen and Pedersen, 2000;Leng, 2004).

Ownership concentration is not the only factor which determine firm's performance. Many studies have shown that number of internal factors affect on firm performance. Among them size, age, debt ratio, quick ratio, inventory level, sales growth and capital turnover are important. (See, Chhibber and Majumdar, 1999; Barbosa and Louri, 2005; Kuntluru, Muppani and Kan, 2008). However, the impact of these factors on financial performance of firms is not same throughout the world. It is differs from country to country, industry to industry and even firm to firm. 
Therefore, objectives of this study can be categorized into two. First objective is to examine the relationship between ownership concentration and financial performance of listed companies at CSE. The second objective is to study the impact of other factors such as, size, age, debt ratio, quick ratio, inventory level, sales growth and capital turnover on financial performance of firms listed at CSE in Sri Lanka.

This study is especially important for managers and investors. Potential and existing investors may use findings to formulate better corporate governance practices as well as to select competitively profitable stocks and to revise portfolios of assets. Managers can use findings to make corporate strategies and investment decisions in the areas of profit goals, leverage, asset management and working capital. This study uses 102 companies listed at CSE, for two consecutive years, 2008 to 2009. Constant coefficients panel data analytic model as well as OLS regression model are used for the data analysis. After ignoring missing data and outliers 162 firm-yearly observations are used for the study under each variable.

Return on asset (ROA) is used to measure the firm performance. Ownership concentration is having an insignificant relation with the ROA. Further, quick ratio, inventory and size are having positive impacts on ROA while debt ratio operates negatively. The remaining of the paper is organized as follows. Section 2 presents review of literature together with variables used in the study. Basic methodology and data are described in section 3. Section 4 contains results of the analysis. Section 5 makes suggestions for further research. The last section is conclusion of the study.

\section{Review of literature}

Papers dealing with the corporate governance and determinants of financial performance are of interest here. This section reviews the findings of past studies under independent and dependent variables. Such classification will make it easy to formulate a model of financial performance measurement of firms listed at CSE.

\section{Dependent variable}

Many researchers prefer to use financial measures to summarize outcomes of economic and other events and transactions already taken place in firms. Financial performance measures indicate whether a company's strategy implementation and execution are contributing to increase profitability. Most of the researchers have used ROA to measure the financial performance of companies. (See., Hansen Wernerfelt, 1989; Mahmood and Mann, 1993; Brown, Gatian and Hicks, 1995; Chhibber and Majumdar, 1999; Barbosa and Louri, 2005 and Kuntluru, Muppani and Kan, 2008). Therefore, this study also uses ROA as the dependent variable for analysis.

\section{Independent variables}

This section discusses the literature on two types of independent variables which have impact on financial performance. First ownership structures and next, other controlling factors which are having an impact on financial performance of firms are addressed separately.

\section{a. Ownership structure and performance}

This section considers the research findings on agency theory. The theory explains the relationship between principles/owners and agents/managers. Generally accepted assumption is that owners desire to maximize profits or wealth. At the same time managers have other interests (high compensation, low effort levels, expense preference, empire buildings etc). 
Therefore, owners need some sort of control over managers to achieve their objective. Ownership concentration is one of the pre-requisites to influence on managers activities.

Thomsen and Pedersen (2000) report that:

In studies of diversification strategy, top managers are assumed to have a personal interest in (product or geographical) diversification at the corporate level because of (employment) risk aversion, expense preference, and empire building. However concentrated ownership might counteract corporate diversification and increase shareholder value.

Top managers prefer to have diversification strategies because of employment risk aversion, expense preference and empire buildings. However, concentrated ownership might counteract diversification \& increase shareholder wealth. Next, empirical findings on the relationship between ownership concentration and firm's profitability are concerned.

As referred in Thomsen and Pedersen (2000), Berle and Means (1932) have found that a positive association between ownership concentration and accounting profitability. Similarly, even in recent period there are evidence that ownership concentrated companies perform financially better than ownership dispersed firms. Lloyed, Hand, and Modani (1987) find that the company market value-to-sales ratio to be greater for ownership concentrated firms. As referred in Thomsen and Pedersen (2000), Zechhouser and Pownd (1990) find that price/ earnings ratio and ownership concentration has a positive relationship. Further, Thomsen and Pedersen (2000), taking a sample of 435 of largest European companies, find that after controlling for other variables, ownership concentration has a positive relation with marketto-book value of equity as well as ROA. However, the effect is level off for high ownership shares. Further, they find that ownership identity has important implications for corporate strategy and performance. More recently, Leng (2004) finds that after controlling the effects of other factors, proportion of shares held by institutional investors significantly influenced on ROE in Malaysian listed companies.

In contrast, Demsetz (1983) points out theoretically that ownership concentration is an endogenous outcome balancing the costs (e.g., risk) and benefits (e.g., monitoring) of ownership. This argument is supported by Demsetz and Lehn (1985) who find that the relationship between ownership concentration and accounting profitability to be not significant when controlling for other variables. Holderness (1988) also finds the same results for majority-owned companies. Subsequently, Gerson and Barr (1996): Pedersen and Thomsen (1999), have supported the Densetz-Lehn model. In order to analyze the monitoring role of large owners on the financial performance, this study introduces the concentrated ownership (CON) of the firm as the main independent variable.

\section{b. Other variables}

Literature on financial performance measures does not propose standard set of factors which determine firm's performance. However, Hansen and Wernerfelt (1989) classify performance differences of firms as arising from firm's internal factors and external factors. This study does not consider external factors to identify performance differences. Cubin and Geroski (1987) and Rumelt (1991) report that industry effect does not contribute significantly to change firm's profitability and instead there are important firm specific dynamic factors. Therefore this section deals with number of internal organizational factors as influential factors on firm's performance. The internal factors considered are: size, age, debt ratio, quick ratio, inventory level, sales growth and capital turnover. 
Empirical studies have shown that size of the firm is positively relate with the financial performance. Chhibber and Majumder (1999) and Kuntluru, Muppani and Kan (2008) find statistically significant positive relationship between firm size and profitability (both ROA and ROS) of Indian firms. Leng (2004) also confirms the above findings in Malaysian companies. When the firm becomes older, it enjoys economics to scale. This means firms can produce products at lower costs and it will cause to increase the revenue and profits.

Age of the firm is an important variable in determining financial performance of firms. When the firm getting older it can enjoy the superior performance compared to new companies. However, if the older firms don't change their systems to cope with the new environmental conditions, their current financial performance would be worse. Kuntluru, Muppani and Khan (2008) find statistically significant positive relationship between age and ROA. However, Chhibber and Majumder (1999) report that the relationship between firm age and profitability (ROA and ROS) is negative.

Capital structure theory reveals that debt financing is favorable to the firm since it delivers tax savings to the firm. Therefore, increasing the level of debts will cause to increase the value of the firm. However, it is shown that bankruptcy-related problems are more likely to arise when a firm includes more debts in capital structure (see, for details, Brigham and Houston, 2004, p. 500). Hence, relationship between capital structure and financial performance of firm can be either negative or positive. Empirical studies find that capital structure is negatively related with the financial performance. Kuntluru, Muppani and Khan (2008) find that debt ratio has a negative significant relationship with ROA and ROS. Barbasa and Louri (2005) and Chhibber and Majumder (1999) also verify it. Thomsen and Pedersen (2000) find a negative relationship between debt equity ratio and ROA in largest European companies.

Inventory is an essential parts for all business operations. Level of inventory and sales has a direct relationship. The shortage of inventory leads to loss in sales and excess inventory may increase excessive carrying cost. Therefore, it is important to study the actual relation between profitability and the inventory. Chhibber \& Majumdar (1999) and Barbosa and Louri (2005) find that the variable inventory is negatively related to profits suggesting the large inventories create a drag on firm's ROA and ROS.

Fixed assets alone are not sufficient to generate performance (profits). Working capital or highly liquid assets are necessary to meet day to day expenses to put fixed assets into operations in order to generate performance. If the firm does not generate sufficient cash flows to meet recurrent expenses then the firm should have to borrow in short-term (current liabilities) or it has to be paid out of permanent capital and eventually the company will go bankruptcy. Therefore, the firm's ability to pay short term liabilities is a key factor determining the performance of a firm. In this study the quick ratio is introduced to capture the relative ability of firms to generate cash and other liquid assets as a proportion of other outstanding current liabilities. Assuming that there is no reason for a firm to keep unnecessarily excess amount of quick assets, the author assume that there is a positive relationship between quick ratio and firm's performance. Barbasa and Louri (2005) and Kuntluru, Muppani and Khan (2008) support this hypothesis.

Market share of a firm determines the relative competitive position of a firm. Kuntluru, Muppani and Khan (2008) predict that competitive positions have an impact on financial performance of a firm. Using sales growth as the indicator of the competitive position, the 
authors find that a significant positive relationship between sales growth and the firms' profitability.

Kuntluru, Muppani and Khan (2008) introduce capital turnover ratio (CTR) to measure how efficiently capital assets are used by the firm. The lower value of the ratio may imply greater efficiency in capital utilization and it will result in higher profitability. Therefore this ratio is supposed to be negatively related with the profitability of the firm. Kuntluru, Muppani and Khan (2008) support this hypothesis.

\section{Data and methodology}

\section{Data}

Total sample of the study consists of 102 companies from 5 largest sectors (excluding Bank, Finance and Insurance sector) in terms of number of companies at CSE for the two years 2008 and 2009. Companies selected for the study under each sector and percentage of sector market capitalization out of total is given in table 1 .

To control the outliers for all the tests remove observations having standardized residuals greater than 3 standard deviations from zero in any yearly regression of depended as well as independent variables. Therefore, finally 162 cross-sectional time series observations are used in 81 firms for the final analysis.

Table 1: Classification of the sample

\begin{tabular}{|l|l|l|}
\hline Sector & $\begin{array}{l}\text { No of } \\
\text { companies }\end{array}$ & $\begin{array}{l}\text { \% of market } \\
\text { capitalization }\end{array}$ \\
\hline Food and Beverage & 15 & 14.89 \\
\hline Hotel & 27 & 12.48 \\
\hline Manufacturing & 28 & 7.83 \\
\hline Plantation & 17 & 4.00 \\
\hline Land and Property & 15 & 3.05 \\
\hline Total & 102 & 42.25 \\
\hline
\end{tabular}

\section{Methodologies}

The study uses the constant coefficient panel data model as well as OLS regression models to analyze the data. Under the constant coefficient model all of the data are pooled and run an OLS regression model. The fundamental assumption behind this model is both intercepts and slopes are constant. That means there is no significant firm effect or temporal effect (time effect) on ROA (see Eq. 1).

ROA $_{i t}=\alpha+\beta_{1}\left(\operatorname{CON}_{i t}\right)++\beta_{2}\left(\right.$ Size $\left._{i t}\right)+\beta_{3}\left(\right.$ Age $\left._{\text {square }_{i t}}\right)+\beta_{4}\left(\right.$ Debt ratio $\left._{i t}\right)+$ $\beta_{5}\left(\right.$ Quick ratio $\left._{i t}\right)+\beta_{6}\left(\right.$ Inventory $\left._{i t}\right)+\beta_{7}\left({\left.\text { Sales } \text { growth }_{i t}\right)}\right)+\beta_{8}\left(\right.$ CTR $\left._{i t}\right)+\varepsilon_{i t}$

Where, $\mathrm{i}=1,2, \ldots ., 81$, and $\mathrm{t}=2008$ and 2009. $\beta$ values represent the regression coefficients of independent variables. In order to detect any timing effect on the ROA, the above regression is run separately for 2008 and 2009. Definition for each variable is given in the following table. 
Table 2: Description of variables

\begin{tabular}{|l|l|}
\hline Variables & Description \\
\hline Dependent variable & $\begin{array}{l}\text { Profit before depreciation, interest and taxes divided by total } \\
\text { assets }\end{array}$ \\
\hline I. ROA & \multicolumn{2}{|l|}{} \\
\hline 2. Ownership concentration (CON) & Ownership share (votes) of the largest owner (\%) \\
\hline 3. Size & Log of total assets \\
\hline 4. Age & $\begin{array}{l}\text { Number of years since incorporation till the date for which data } \\
\text { are incorporated }\end{array}$ \\
\hline 5. Debt ratio & Total debt to total assets \\
\hline 6. Quick ratio & Ratio of quick assets to total current liabilities \\
\hline 7. Inventory & Ratio of inventory investment to total assets \\
\hline 8. Sales growth & Ratio of current year to previous year's sales \\
\hline 9. Capital turn over ratio (CTR) & Ratio of net fixed assets to sales \\
\hline Source: author's processing &
\end{tabular}

\section{Results}

Table 3 and 4 provide descriptive statistics of mean, standard deviation, maximum and minimum values for each variable. The table shows that average ownership concentration is $47 \%$ and it is ranges between maximum of $97 \%$ to minimum of $0.07 \%$. it shows that the ownership concentration in the sample is well dispersed between two ranges.

Table 4 provides correlation matrix for the independent variables. As indicated in the table quick ratio is having a moderately negative correlation with debt ratio $(\mathrm{r}=-0.35)$. Further, capital turnover having moderately negative correlation with inventory $(\mathrm{r}=-0.43)$. No any other pair of variables shows significant correlations. Hence, the table reveals that independent variables are free from multicolinearity problem.

Table 3: Pooled sample descriptive statistics

\begin{tabular}{|c|c|c|c|c|}
\hline & Mean & $\begin{array}{l}\text { Standard } \\
\text { deviation }\end{array}$ & Maximum & Minimum \\
\hline ROA & 0.06 & 0.11 & 0.65 & -0.25 \\
\hline Con & 0.47 & 0.23 & 0.97 & 0.07 \\
\hline Age & 27.00 & 14.40 & 82.00 & 4.00 \\
\hline Sales growth & 0.075 & 0.20 & 0.83 & -0.37 \\
\hline Size & 14.40 & 1.04 & 16.75 & 11.42 \\
\hline Debt ratio & 1.19 & 1.20 & 6.85 & 0.001 \\
\hline Inventory & 0.12 & 0.10 & 0.46 & 0.00 \\
\hline Quick ratio & 0.92 & 0.80 & 5.71 & 0.05 \\
\hline CTR & 1.78 & 3.38 & 31.49 & 0.02 \\
\hline
\end{tabular}

* Measured by log value of total assets

Source: survey data

Regression results are shown in table 5, 6 and 7. Table 5 presents the regression (constant coefficient model) estimates of the coefficients of equation 1 for a measure of financial performance using the ROA as the dependent variable. The panel A of the table presents the analysis of variance (ANOVA) for the model and the panel B of the table shows regression coefficients with their t-values. 
Table 4: Correlation among independent variables

\begin{tabular}{|l|l|l|l|c|c|c|c|c|}
\hline & CON & Age & $\begin{array}{l}\text { Sales } \\
\text { growth }\end{array}$ & Size & $\begin{array}{l}\text { Debt } \\
\text { ratio }\end{array}$ & $\begin{array}{l}\text { Quick } \\
\text { ratio }\end{array}$ & Inventory & CTR \\
\hline CON & 1 & 0.13 & -0.16 & 0.21 & 0.02 & -0.05 & -0.04 & 0.12 \\
\hline Age & & 1 & -0.07 & 0.00 & -0.12 & -0.17 & 0.09 & 0.26 \\
\hline Sales growth & & & 1 & -0.03 & -0.06 & 0.11 & -0.08 & 0.03 \\
\hline Total assets & & & & 1 & 0.06 & -0.09 & -0.04 & 0.07 \\
\hline Debt ratio & & & & & 1 & -0.35 & 0.25 & -0.24 \\
\hline Quick ratio & & & & & & 1 & -0.10 & -0.02 \\
\hline Inventory & & & & & & & 1 & -0.43 \\
\hline CTR & & & & & & & & 1 \\
\hline
\end{tabular}

Source: survey data

The total model explains $35.83 \%\left(\mathrm{R}^{2}\right)$ of the variability of $\mathrm{ROA}(\mathrm{F}=10.68186, \mathrm{P}<0.01)$. Panel $\mathrm{B}$ of the table shows that size, debt ratio, quick ratio, inventory, having significant effects on ROA.

Panel B of the table reports that ownership concentration has no significant impact on the performance of companies at CSE. This seems that either largest owners tend to place more emphasis on non profit objectives of the firms or cost of monitoring the activities of managers may be higher than the benefits of ownership concentration. This finding is similar to the Demsetz and Lehn (1985) who find that the relationship between ownership concentration and accounting profitability to be not significant when controlling for other variables. Holderness and Sheehan (1988) also find the same results for majority-owned companies. Subsequently, Gerson and Barr (1996) and Pedersen and Thomsen (1999) also come to the same conclusions.

Table 5: Results of regression analysis using constant coefficient model Panel-A

\begin{tabular}{|c|c|c|c|c|c|}
\hline \multicolumn{6}{|l|}{ ANOVA } \\
\hline & $d f$ & $S S$ & $M S$ & $F$ & Significance $F$ \\
\hline Regression & 8 & 0.72055 & 0.09007 & 10.68186 & $7.2 \mathrm{E}-12$ \\
\hline Residual & 153 & 1.29009 & 0.00843 & & \\
\hline Total & 161 & 2.01065 & & & \\
\hline \multicolumn{6}{|l|}{ Panel-B } \\
\hline \multicolumn{3}{|c|}{ Variable } & \multicolumn{2}{|c|}{ Coefficient } & t-statistic \\
\hline \multicolumn{3}{|l|}{$\mathrm{CON}$} & \multicolumn{2}{|c|}{0.026} & 0.80 \\
\hline \multicolumn{3}{|l|}{ Age } & \multicolumn{2}{|c|}{0.001} & 0.265 \\
\hline \multicolumn{3}{|l|}{ Sales growth } & \multicolumn{2}{|c|}{0.000} & 0.173 \\
\hline \multicolumn{3}{|l|}{ Size } & \multicolumn{2}{|c|}{0.028} & $4.04 * * *$ \\
\hline \multicolumn{3}{|l|}{ Debt ratio } & \multicolumn{2}{|c|}{-0.016} & $-2.42 * *$ \\
\hline \multicolumn{3}{|l|}{ Inventory } & \multicolumn{2}{|c|}{0.511} & $6.34 * * *$ \\
\hline \multicolumn{3}{|l|}{ Quick ratio } & \multicolumn{2}{|c|}{0.023} & $2.34 * *$ \\
\hline \multicolumn{3}{|l|}{ CTR } & \multicolumn{2}{|c|}{-0.004} & -1.64 \\
\hline \multicolumn{6}{|c|}{$\mathrm{R}^{2}=35.83$} \\
\hline
\end{tabular}

The size variable is having statistically significant positive effect on ROA. This means when the firm becomes larger and larger its ability to generate returns gradually improving. This finding proves the micro economic theory of economics to scale. Further, the results are in accordance with the Chhibber and Majumder (1999) and Kuntluru, Muppani and Kan (2008) who find statistically significant positive relationship between firm size and profitability 
(both ROA and ROS) of Indian firms. Leng (2004) also confirms the above findings in Malaysian companies.

Quick ratio shows positive and statistically significant impact on ROA. This finding is similar to the Chhibber \& Majumdar (1999). The average quick ratio is 0.92 (see, table 2) and it reflects the working capital management bench mark as well as the firm level cash management capabilities that are unobservable. The finding shows that efficient cash management, debtors and creditors administration are key factors for better financial performance.

Nonetheless, debt ratio having a negative relationship with the profitability of the firms ( $\beta=-0.016, t=-2.42)$. This means when the capital structure consists of more debts it cause to decrease profitability of the firm. It seems that the excess debts increase the financial distress costs and decrease the value of the firm. This finding is similar to the Chhibber and Majumder (1999), Thomsen and Pedersen (2000) and Barbasa and Louri (2005).

Inventory effect increases as firms attain high profits, indicating that the relevance of inventory decisions increase as firms improve their performance. Therefore, firms should keep sufficient level of inventories to achieve better financial performance. This is an opposite finding to the Chhibber and Majumdar (1999) and Barbasa and Louri (2005).

Table 6: Results of regression analysis using constant coefficient model 2008

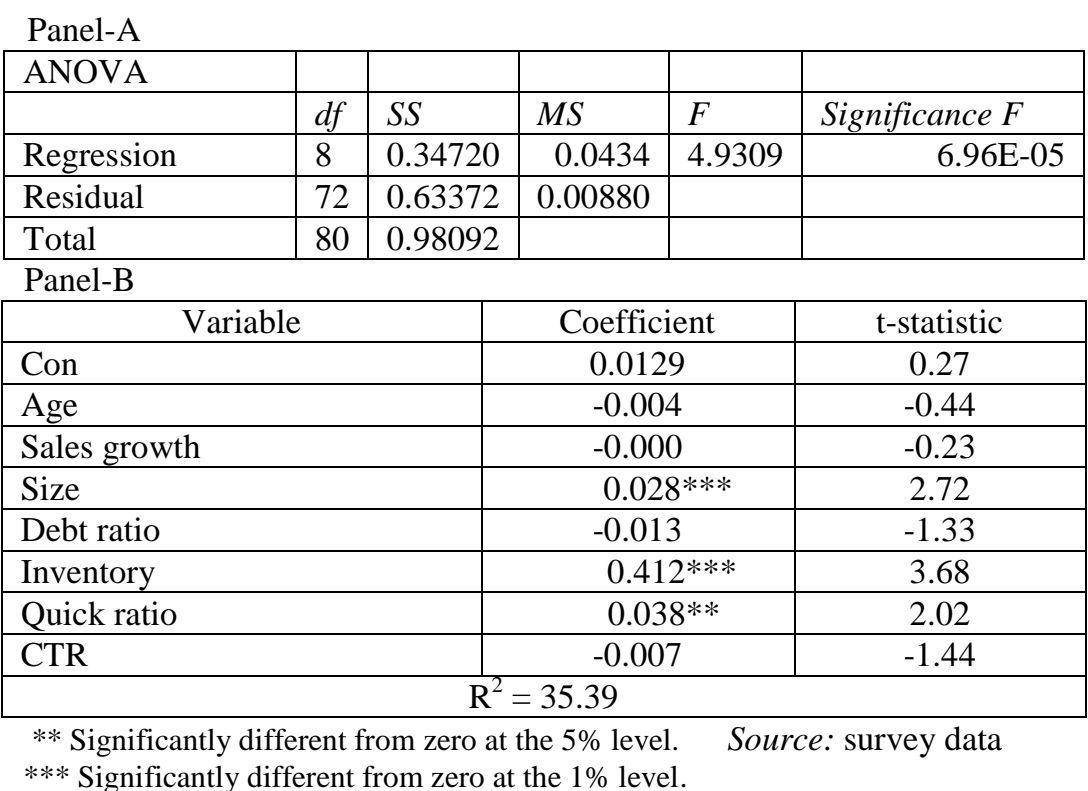

Table 6 shows OLS regression results for the year 2008. The model explains $35.39 \%\left(\mathrm{R}^{2}\right)$ of the variability of ROA $(\mathrm{F}=4.9309, \mathrm{P}<0.01)$. Panel $\mathrm{B}$ of the table shows that size variable, inventory and quick ratio having positive impacts on the ROA. However, contrary to total sample, the negative impact of debt ratio on ROA is not statistically significant in the year 2008.

The table 7 shows the OLS regression results for the model 1 only for the year 2009. It seems that the model explanatory power has improved in the year 2009 explaining the $40.61 \%\left(\mathrm{R}^{2}\right)$ of the variability of ROA $(\mathrm{F}=6.15611, \mathrm{P}<0.01)$. Panel $\mathrm{B}$ of the table shows that size variable, and inventory having positive impacts on the ROA. Debt ratio is having significant 
negative effects on ROA $(\beta=-0.019, \mathrm{t}=-1.94)$. However, contrary to total sample, the positive impact of quick ratio on ROA is not statistically significant in the year 2009 .

Table7: Results of regression analysis using constant coefficient model 2009

Panel-A

\begin{tabular}{|c|c|c|c|c|c|}
\hline ANOVA & & & & & \\
\hline & $d f$ & $S S$ & $M S$ & $F$ & Significance $F$ \\
\hline Regression & 8 & 0.41405 & 0.05175 & 6.15611 & $4.91 \mathrm{E}-06$ \\
\hline Residual & 72 & 0.60533 & 0.00840 & & \\
\hline Total & 80 & 1.01938 & & & \\
\hline
\end{tabular}

Panel-B

\begin{tabular}{|l|c|c|}
\hline \multicolumn{1}{|c|}{ Variable } & Coefficient & t-statistic \\
\hline CON & 0.048 & 1.02 \\
\hline Age & 0.010 & 1.01 \\
\hline Sales growth & -0.032 & -0.59 \\
\hline Size & 0.028 & $2.79^{* * *}$ \\
\hline Debt ratio & -0.019 & $-1.94^{*}$ \\
\hline Inventory & 0.600 & $4.69^{* * *}$ \\
\hline Quick ratio & 0.019 & 1.63 \\
\hline CTR & -0.003 & -1.18 \\
\hline \multicolumn{2}{|l}{} \\
\hline
\end{tabular}

* Significantly different from zero at the $10 \%$ level. Source: survey data $* * *$ Significantly different from zero at the $1 \%$ level

\section{Further research}

The strength of statistical model used in the study report in table 5, 6 and 7 is below average $\left(\mathrm{R}^{2}=35.83,35.39\right.$ and 40.61 respectively). This means, there are some omitted factors which would increase the robustness of the model. Finally, study is confined to 81 firms only. Therefore, the researcher could not examine the ownership concentration effect on different levels of ownership as well as ownership identity effect on financial performance. Tomas and Petersen (2000) find that there is no effect on financial performance when the ownership is highly concentrated on one owner. Further, they find that ownership identity also a matter on share value. Therefore, in a further study more firms on different levels of ownership concentration should be studied separately. At the same time it is important to study the ownership concentration with different ownership identities such as institutional investors, government investors and individual investors.

One of the major limitations of the model is the ignorance of industry effects. Barbosa and Louri (2005) report that Firms operating in Greece are found to be sensitive to industry characteristics, such as concentration, $R \& D$ intensity and growth. Therefore, it is important to consider the industry factors as a further research.

Further, studies have found that enterprises receiving foreign investment, or under foreign ownership, outperformed their domestic counterparts (Djankov and Hoekman, 2000). Harun and Deniz(2008) and Kuntluru, Muppani and Khan (2008) also support this view. Therefore, it is better to examine the impact of foreign direct investment (FDI) on financial performance of Sri Lankan firms. 


\section{Conclusion}

This study attempted to identify the impact of share of the largest owner and other controlled variables on ROA of the selected listed companies in Sri Lanka. The other variables used in the study are size, age, debt ratio, quick ratio, inventory level, sales growth and capital turnover. Cross-sectional time series analysis is used for the analysis of data for the total sample and OLS regression for the analysis of data for individual years. Data gathered through the annual reports of the respective companies.

Study finds that ownership concentration having a positive impact on the ROA but it is not statistically significant. On overall basis, size, quick ratio, inventory, are having significant positive effects on ROA. Where as, the impact of debt ratio is negative on ROA.

The findings have important managerial implications. First, firms should keep adequate level of quick assets to meet the liquidity requirements. Further, inventory management is important to have better financial performance. Next, firm's capital structure should not contain more debts. This is more relevant when the macro economic condition is not favorable. This study has several implications for investors also. If investors want to take the stake of the company, they have to think about appropriate monitoring measures to govern the activities of managers so that all efforts of managers and scare resources of the company generate value to shareholders. Further, it is worth investors to take into account the size of the company in terms of asset base when making investment decisions. Findings of the study show that the overall explanatory power of the model is below average and further research is needed with new explanatory variables. One potentially fruitful extension of this study would be to identify industry effects on financial performance. Further, ownership identity, level of foreign direct investments would be important to consider for the analysis. It is worth for financial data to be supplemented with data on qualitative variables such as management style and employee attitudes.

\section{References}

[1] BARBOSA, N. and H. LOURI, 2005. Corporate Performance: does ownership matter? A comparison of foreign-and domestic-owned firms in Greece and Portugal. Review of Industrial Organization, vol. 27, p. 73-102. ISSN: 1573-7160.

[2] BRIGHAM, E. F. and J. F. HOUSTON, (2004)10 ${ }^{\text {th }}$ edition. Fundamentals of Financial Management, Thomson South-Western. ISBN 0-324-178298.

[3] BROWN, S., L. KIN and T. LYS, 1999. Use of $\mathrm{R}^{2}$ in Accounting Research: Measuring Changes in Value Relevance over the Last four Decades,' Journal of Accounting \& Economics, (Vol. 28, no.2, p. 83-115. ISSN:0165-4101

[4] CHHIBBER, P. K. and S. K. MAJUMDAR, 1999. Foreign ownership and profitability: property rights, control and the performance of firms in Indian Industry. Journal of Law and Economics, vol.46, no.3, p.209-238. ISSN: 00222186.

[5] CUBBIN, J. and P. A. GEROSKI, 1987. The Convergence of Profits in the Long Run: Inter firm and Inter-industry Comparisons, Journal of Industrial Economics, vol.35, p. 427-442. ISSN:1467-6451

[6] DEMSETZ, H., 1983. The structure of ownership and the theory of the firm. Journal of Law and Economics, vol.26, no.2. p.375-394. ISSN: 00222186. 
[7] DEMSETZ, H. and K. LEHN, 1985. The structure of corporate ownership: causes and consequences. Journal of Political Economy, vol. 93, no.6. p. 1155-1177. ISSN: 00223808 .

[8] DJANKOV, S. and B. HOEKMAN, 2000. Foreign Investment and Productivity Growth in Czech Enterprises. The World Bank Economic Review, vol. 14, no.1, p.49-64. ISSN: 0258-6770.

[9] GERSON, J. and G. BARR, 1996. The structure of corporate control and ownership in a regulatory environment unbiased toward one-share-one-vote. Corporate Governance, vol. 4. no.2, p.78-93. ISSN: 1467-8683.

[10] HANSMANN, H., 1988. Ownership of the firm. Journal of Law. Economics and Organization, vol.4, no.2, p.267-305. ISSN $0354-4699$.

[11] HANSE, G.S. and B. WERNERFELT, 1989. Determinants of Firm performance: the relative importance of economic and organizational factors. Strategic management Journal, vol. 10, p.399-411. ISSN: 1097-0266.

[12] HARN, K. and E. DENIZ, 2008. Firm-specific capabilities and foreign direct investment activities of Turkish manufacturing firms. Journal of management Development, vol. 27, no. 7, p. 761-777. ISSN: 0262-1711.

[13] KUNTLURU, S., V. R. MUPPANI and M. A. ALI KHAN, 2008. Financial performance of foreign and domestic owned companies in India. Journal of AsiaPacific Business, vol. 9, no.1, p.28-54. ISSN: 1528-6940.

[14] LENG, A., 2004. A.C. The Impact of Corporate Governance Practices on Firms' Financial Performance. Evidence from Malaysian Companies. SEAN Economic Bulletin, vol. 21, no. 3, p. 308-18.

[15] LLOYD, W. P., J. H. HAND and N. K. MODANI, 1998. The effect of the degree of ownership control on firm diversification, market value, and merger activity. Journal of Business Research, vol. 15, no.4, p. 303-312. ISSN: 0148-2963.

[16] MAHMOOD, MO A. and J. M. GARY, 1993. Measuring Technological Impact of Information Technology investment: An Exploratory study. Journal of Management Information systems, vol. 10, no.1, p.97-122. ISSN: 0742-1222.

[17] RUMELT, R. P., 1991. How Much Does Industry Matter?'. Strategic Management Journal, vol.12, no.3, p. 167-185. ISSN: 1097-0266.

[18] THOMSEN, S. and T. PEDERSEN, 2000. Ownership structure and economic performance in the largest European Companies. Strategic Management Journal, vol.21, p. 689-705. ISSN: 1097-0266. 